Vol. 51, n. 5 : pp.1011-1014, September-October 2008 ISSN 1516-8913 Printed in Brazil
BRAZILIAN ARCHIVES OF BIOLOGY AND TECHNOLOGY

AN INTERNATIONAL JOURNAL

\title{
An Inexpensive Alternative Equipment for the Plant Material Embedding in the Paraffin under the Vacuum
}

\author{
Carlos André Espolador Leitão $^{1}{ }^{*}$ and Angelo Luiz Cortelazzo ${ }^{2}$ \\ ${ }^{1}$ Departamento de Ciências Naturais; Universidade Estadual do Sudoeste da Bahia; Estrada do Bem Querer; Km \\ 04; candreel@yahoo.com.br; 45083-900; Vitória da Conquista - BA - Brasil. ${ }^{2}$ Departamento de Biologia Celular; \\ Universidade Estadual de Campinas; 13083-863; Campinas - SP - Brasil
}

\begin{abstract}
The present work describes an equipment constructed using inexpensive material for embedding the plant material in the paraffin under the vacuum, using an oven and a vacuum pump. The equipment was tested using the samples of Rodriguezia venusta (Orchidaceae) buds embedded in paraffin, where half of the samples were submitted to the vacuum by the equipment during the embedding. The material was sectioned with a rotary microtome, obtaining full series of quality sections. The control was hard to section with the microtome, obtaining damaged sections due the air bubbles, making the ribbon formation difficult. These results proved the effectiveness of the equipment, making it a practical, inexpensive and more portable solution for newly established laboratories.
\end{abstract}

Kew words: Embedding, paraffin method, plant anatomy, technique in microscopy

\section{INTRODUCTION}

The paraffin embedding is a crucial step in preparing the permanent slides of the material sectioned with a microtome. For a structural study based on the serial sections, it is necessary to have good sectioning, so as to easily obtain the ribbons of the sections and, therefore, preserve the full series. The inclusion of the compact plant organs is usually easy, but the structures with many trichomes or air bubbles, as occurs in the buds, frequently are difficult to embed. There are many models of vacuum ovens but this equipment is expensive and bulky, and often inaccessible to newly established laboratories or field laboratories. Alternative methodologies can provide several facilities and efficient results contributing to the enhancement of the research in developing countries (Jordão and Takaki, 1986; Takaki, 1987). Thus, the objectives of this study were to construct a low cost equipment that could maintain the paraffin in the liquid state at a controlled temperature and under the vacuum and to analyze the equipment's efficiency to obtain easily sectioned material forming the ribbon of serial sections during the microtomy.

\section{MATERIALS AND METHODS}

\section{Equipment construction}

To make the equipment, was employed a transparent $500 \mathrm{~mL}$ flask with a wide mouth, a flexible, copper tube, $5 \mathrm{~mm}$ wide and $1 \mathrm{~m}$ long, a

* Author for correspondence 
portion of $1 / 2$ inch PVC pipe, three rubber stoppers and $1 \mathrm{~m}$ of latex tubing. The equipment was mounted as in Figures $1 \mathrm{~A}$ and $1 \mathrm{~B}$ (schematic drawings). The PVC pipe was sawed to fit vertically in the wide mouthed flask, which was covered with the large stopper so that the pipe rested on the flask bottom and was supported by the contact with the stopper. Using a hot nail, three holes were made near the top of the PVC pipe.
These holes should remain free even after plugging the pipe. The holes were made through the large stopper and a small one. This smaller one was introduced firmly in the upper end of the PVC pipe and the portion of the stopper rising above the pipe was cut off with a blade. The copper tube was threaded through the two stoppers, coupling them. The bottom of the PVC pipe was closed with a stopper, without hole.

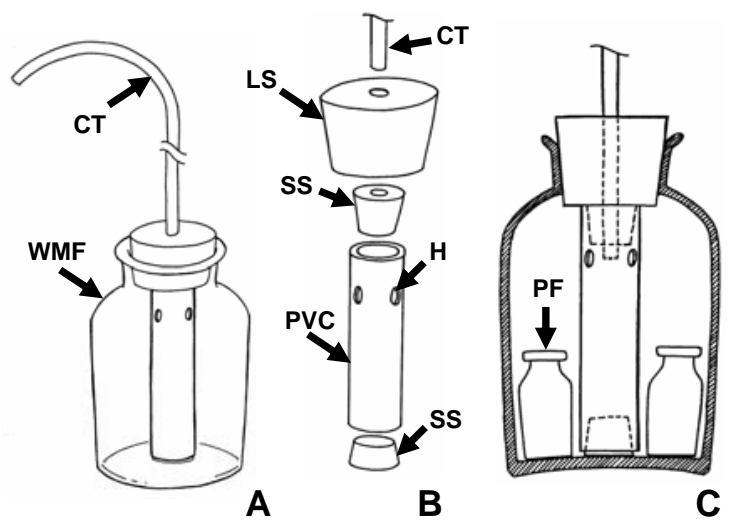

Figure 1 - Diagrams of the equipment for paraffin embedding under vacuum. A) General view of the mounted equipment without the embedding samples. B) Internal components of the equipment before the mounting. C) Wide mouth flask sectioned longitudinally, with the mounted equipment, showing the arrangement of the penicillin flasks, containing the samples being embedded. The traced lines indicate internal edges of components. CT- copper tube; H- hole; LS - large stopper; PF- penicillin flask; PVC- $1 \frac{1}{2}$ inch PVC pipe; SS- smaller stoppers; WMF- wide mouthed flask.

\section{Operating the equipment}

To test the equipment's efficiency, the flower buds of Rodriguezia venusta (Lindl.) Rchb. f. (Orchidaceae) were collected, fixed in $\mathrm{FAA}_{50}$, dehydrated in a graded ethanol/butanol series and embedded in the butanol and paraffin (1/1). The embedding paraffin baths occurred with the samples packed in the penicillin flasks. The flasks containing the samples embedded in the butanol and paraffin were covered and placed in an oven at $59^{\circ} \mathrm{C}$. Two hours later, the covers were removed and the flasks returned to the oven for $6 \mathrm{~h}$. At the first pure paraffin bath, they were placed with the help of clawed tweezers inside a previously heated $500 \mathrm{~mL}$ flask (Fig. 1C). The copper tube was introduced into the oven through the hole made to pass a thermometer. The large flask, containing the penicillin flasks was placed in the oven and stopped. The copper tube outside the oven was connected to the vacuum pump (Primar $\left.{ }^{\circledR}, \bmod .141\right)$ with the latex tubing. When the paraffin was liquefied, the vacuum pump was turned on (Fig. 2) with vacuometer registering $50 \mathrm{~cm} . \mathrm{Hg}$. After the bubble formation, the latex tubing was clamped and the vacuum pump was turned off, leaving the flask in the oven for $2 \mathrm{~h}$ before opening the oven. The material was embedded in paraffin with $4 \%$ beeswax in the paper trays, making paraffin blocks. The control material was identically processed but without the vacuum step. 


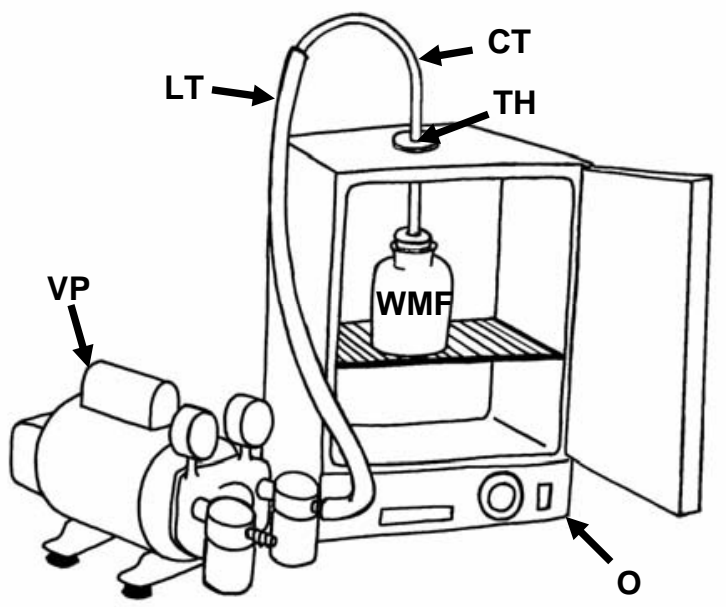

Figure 2 - Diagram of the mounted equipment showing the oven and the vacuum pump. CTcopper tube; LT- latex tubing; O- oven; TH- hole originally made for passing a thermometer; VP- vacuum pump; WMF- wide mouthed flask, mounted with the samples.

The procedure was performed five times and at least three hundred sections $(8 \mu \mathrm{m}$ thick) were obtained for each one, with a rotary microtome.The paraffin was removed using the xylol and the sections were hydrated in a regressive ethanol series, stained with the Toluidine Blue in the McIlvaine buffer at $\mathrm{pH} 4.0$ (O'Brien and McCully, 1981), washed in the distilled water and air dried. The slides were mounted with the Canada balsam (Berlyn and Miksche, 1976) and observed with a light microscope.

\section{RESULTS AND DISCUSSION}

The sections of the material embedded in the paraffin under the vacuum formed the ribbons easily, making it possible to attain the full series in the three repetitions (Fig. 3A). However the control material was very difficult to section, presenting many large and deep air bubbles (Fig. 3B). Sectioning the paraffin blocks with the bubbles, it was practically impossible to obtain the ribbons, making it impossible to obtain a full series of the sections.
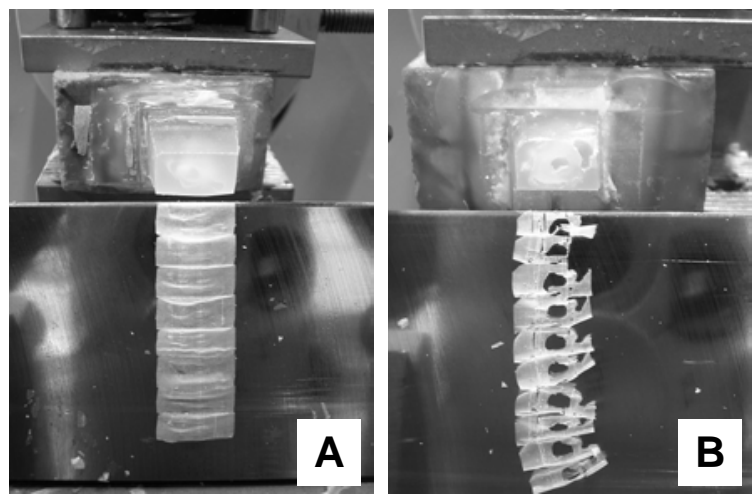

Figure 3 - Photographs showing the paraffin blocks with samples, cut with a rotary microtome, and the ribbons of sections extending over the knife. A) Blocks of material submitted to vacuum during paraffin embedding. B) Control not submitted to vacuum during paraffin .embedding. 
After the staining and mounting the slides, the sections prepared using both the treatments were similar in the quality for the anatomic and cytological studies. However, the material not submitted to the vacuum during the paraffin embedding did not have all the necessary information mainly due to the loss of many sections.

The construction of the vacuum embedding equipment described in this work was inexpensive and quickly mounted, using the material easy to find. The operation is also easy, although care must be taken to avoid the tipping over the penicillin flasks, especially when moving, or opening and closing the large flask. Despite the fact that the sections were attained with both the procedures, the fact that a full series could not be obtained for those not embedded under the vacuum, made this procedure highly desirable. The equipment for the paraffin embedding under the vacuum presented can be the best option for obtaining a full series of the plant material with the air pockets, such as buds.

\section{ACKNOWLEDGEMENTS}

We thank Prof ${ }^{\mathrm{a}} \operatorname{Dr}^{\mathrm{a}}$ Heidi Dolder for revising the English of this manuscript. C. A. E. Leitão received a fellowship from Universidade Estadual do Sudoeste da Bahia - UESB, Brasil, during this work.

\section{RESUMO}

$\mathrm{O}$ presente trabalho apresenta um equipamento feito com material barato, destinado à inclusão de material botânico em parafina sob vácuo, utilizando-se uma estufa e uma bomba de vácuo. $\mathrm{O}$ equipamento foi testado utilizando-se amostras de botão floral de Rodriguezia venusta (Orchidaceae) incluídas em parafina, das quais metade foi submetida ao vácuo pelo equipamento durante a infiltração.
O material foi seccionado em micrótomo rotativo, obtendo-se séries completas de cortes de boa qualidade das amostras submetidas ao vácuo. $\mathrm{O}$ controle foi de difícil microtomia, obtendo-se cortes danificados pela presença de bolhas de ar, dificultando assim a formação de fitas. Estes resultados comprovam a eficácia do equipamento proposto, sendo este uma solução prática, barata e portátil para laboratórios em início de estruturação.

\section{REFERENCES}

Berlyn, G. P. and Miksche, J. P. (1976), Botanical Microtechnique and Cytochemistry. Iowa State University Press, Iowa.

Jordão, L. R. and Takaki, M. (1986), An efficient microbiological hood. Arq. Biol. Tecnol., 29, $297-$ 299.

O'Brien, T. P. and McCully, M. E. (1981), The study of plant structure principles and selected methods. Termarcarphi, Melbourne.

Takaki, M. (1987). An eppendorf centrifuge with a blendor. Arq. Biol. Tecnol., 30, 633-634. 